\title{
Aegle marmelos fruit extract attenuates Helicobacter pylori Lipopolysaccharide induced oxidative stress in Sprague Dawley rats
}

\author{
Yarasi Gayathri Ramakrishna ${ }^{1}$, Kumarasamy Savithri ${ }^{1}$, Manfred Kist ${ }^{2}$ and Sivasitamparam Niranjali Devaraj ${ }^{1 *}$
}

\begin{abstract}
Background: Bael (Aegle marmelos (L.) Corr.) has been widely used in indigenous systems of Indian medicine to exploit its medicinal properties including astringent, antidiarrheal, antidysenteric, demulcent, antipyretic, antiulcer, anti-inflammatory and anti cancer activities. The present study aims to evaluate the antioxidative and antiulcer effect of methanolic extract of unripe fruit of Aegle marmelos (MEAM) against Helicobacter pylori-Lipopolysaccharide (HP-LPS) induced gastric ulcer in Sprague Dawley (SD) rats.

Methods: Dose and duration of HP-LPS and MEAM were fixed based on ulcer index of gastric tissue of experimental animals. Various gastric secretory parameters such as volume of gastric juice, free and total acidity, acid output, pepsin concentration were analyzed. The activities of enzymatic antioxidants (superoxide dismutase, catalase, glutathione peroxidase, glutathione reductase and glutathione transferase), non-enzymatic antioxidants (reduced glutathione, vitamin C and vitamin E) and the levels of lipid peroxidation products were measured. Histological analysis was performed to evaluate the effect of Aegle marmelos on HP-LPS induced gastric ulcer.

Results: Oral administration of HP-LPS (50 $\mu \mathrm{g}$ per animal) for four consecutive days resulted in induction of ulcer with the increase in gastric secretory parameters such as volume of gastric juice, free and total acidity, acid output, pepsin concentration. Oral administration of methanolic extract of Aegle marmelos fruit (MEAM) (25, 50, 100, 250 and $500 \mathrm{mg} / \mathrm{kg}$ ) reduced the gastric ulcer by $2.8 \%, 52.4 \%, 73 \%, 93 \%$ and $93.98 \%$, respectively, compared to $89.2 \%$ reduction by sucralfate $(100 \mathrm{mg} / \mathrm{kg})$. MEAM treatment significantly $(p<0.05)$ inhibited the increase in gastric secretory parameters in ulcerated rats, and it also prevented the reduction of enzymatic (superoxide dismutase, catalase, glutathione peroxidase, glutathione reductase and glutathione transferase) and non-enzymatic antioxidants (reduced glutathione, vitamin C and vitamin E) after HP-LPS induction. In addition, lipid peroxidation was inhibited by MEAM in HP-LPS induced rats. Results of histological analysis correlated well with biochemical parameters.
\end{abstract}

Conclusion: These observations explored the antioxidant properties of MEAM contributing to the gastroprotective effect in HP-LPS induced gastric ulcer model.

Keywords: Helicobacter pylori lipopolysaccharide, Aegle marmelos, Antioxidants, Gastric ulcer

\footnotetext{
* Correspondence: niranjali@yahoo.com

'Department of Biochemistry, University of Madras, Guindy Campus, Chennai 600025, India

Full list of author information is available at the end of the article
} 


\section{Background}

Helicobacter pylori (H. pylori) is a highly prevalent bacterial gastroduodenal pathogen of humans infecting almost $50 \%$ of the world's population, and most infected individuals remain asymptomatic [1]. H. pylori is now recognized as a causative factor of chronic gastritis, gastroduodenal ulcer, gastric cancer and mucosa-associated lymphatic tissue lymphoma [2,3]. Several factors of $H$. pylori mediate cytotoxicity and the inflammatory reaction. Among these are, vacuolating toxin (VacA), ammonium ions produced by urease, cytotoxin associated gene A (CagA) protein, the type IV secretion system and lipopolysaccharide (LPS) $[4,5]$.

In general, Gram-negative bacterial Lipopolysaccharides are key inflammation inducers. However, Helicobacter pylori-Lipolysaccharide (HP-LPS) shows extremely low endotoxic activity in comparison to typical Gram-negative bacterial LPS, such as those from Escherichia coli, which makes it to potentially contribute to the persistence of infection [6-9]. Helicobacter pylori, being a Gram-negative bacterium that colonizes the gastric mucosa, is recognized as a primary cause of gastric disease, and its cell-wall lipopolysaccharide has been identified among the key virulence factors responsible for eliciting mucosal inflammatory responses that characterize gastritis and duodenal ulcers [10-14]. The gastric mucosal responses associated with $H$. pylori infection in humans as well as those characterizing mucosal inflammatory changes in the animal model of HP-LPS induced gastritis are manifested by a marked increase in epithelial cell apoptosis and proinflammatory interleukin expression, excessive nitric oxide and prostaglandin generation, and the disturbances in $\mathrm{NFKB}$ and MAPK signaling cascades [15-18]. HP-LPS has been implicated in the stimulation of pepsinogen and histamine secretion, inhibition of sulfated mucin synthesis, and the production of potentially destructive auto-antibodies, which may all contribute to the loss of mucosal integrity [19]. In addition, HP-LPS was shown to bind to the gastric mucosal somatostatin receptor, thereby interfering with the regulatory effect of somatostatin on gastric mucosal G cell function [20]. Pathogen-induced inflammation is associated with an increase in Reactive Oxygen Species (ROS) and Reactive Nitrogen Species (RNS) production and the activation of the inflammatory response depletes tissue antioxidants and exposes the host to increased risk of oxidative stress [21, 22].

Eradication of $H$. pylori seems to cure both infection and ulcers. Successful treatment therefore leads to the resolution of gastritis and reduces the likelihood of ulcer recurrence [23]. The combination of a proton pump inhibitor (e.g. omeprazole) and antibiotics (i.e. ampicillin, amoxicillin, ofloxacin or tetracycline) is curative in up to $90 \%$ of patients [24].
Many infectious diseases are known to be treated with herbal remedies throughout the history of mankind. Plant materials continue to play a major role in primary health care as therapeutic remedies in many developing countries. Plants still continue to be almost the exclusive source of drugs for the majority of the world's population. The World Health Organization reported that $80 \%$ of the world's population rely chiefly on traditional medicine and a major part of the traditional therapies involve the use of plant extracts or their active constituents [25]. Several plants are used for the treatment of gastric ailments, including stomach ache and ulcers [26-31]. Medicinal plants are recognized as rich sources of natural antioxidants that can protect against inflammationassociated oxidative stress with their added advantages, such as less toxicity, affordability and medicinal as well as traditional values. One such traditionally used medicinal plant since ancient times is Aegle marmelos Correa, commonly known as Bael, which belongs to the family Rutaceae. Each and every part of the plant such as fruit, seed, leaf, bark and root is known for its therapeutic and medicinal value. The bael fruit pulp contains many functional and bioactive compounds such as carotenoids, phenolics, alkaloids, coumarins, flavonoids, terpenoids, and other antioxidants which may protect us against chronic diseases. A major constituent of the fruit is the mucilage and marmelosin (0.5\%), a coumarin. In addition, it also contains many vitamins and minerals including vitamin $\mathrm{C}$, vitamin $\mathrm{A}$, thiamine, riboflavin, niacin, calcium, and phosphorus [32]. It should be noted that the unripe fruits are bitter, acrid, sour, and astringent; aid digestion and stomach irritation; and are useful in treating diarrhea, dysentery, and stomachalgia [33].

Inspite of its long traditional usage in Indian medicine, antioxidant and antiulcer properties of Aegle marmelos fruit have not been studied in vivo using HP-LPS induced Sprague Dawley (SD) rats as a model. A previous study on gastric ulcer induced by aspirin in albino rats has shown the protective effect of Aegle marmelos fruit [34]. In a similar study, the ripe fruit pulp of AM shows gastrointestinal cytoprotective activity in Aspirin-induced, Cold-restraint stress-induced and Cerebellar lesion-induced ulcer models through the release of Serotonin (5-hydroxytryptamine; 5-HT) from enterochromaffin (EC) cells [35]. Hence, the present study was aimed to investigate the antioxidative effect of methanolic extract of unripe fruit of Aegle marmelos against HP-LPS induced gastric ulcer in SD rats. Secretory parameters and analyses of antioxidative enzymes were carried out using biochemical assays. These results were further confirmed by histological analysis. 


\section{Methods}

Preparation of methanolic extract of unripe fruit of Aegle marmelos (MEAM)

The fruits of $A$. marmelos were collected from Marudeeswarar temple, Thiruvanmiyur, TamilNadu, India during the month of March 2009. The plant material was identified by Dr. Mathivanan, Professor, Centre for Advanced Study in Botany, University of Madras, Guindy Campus, Chennai, Tamilnadu, India and the specimen was deposited in the same.

The fruits were cut open, deseeded, shade dried, and ground mechanically. Dried fruit material (500 g) was first defatted with $\mathrm{n}$-hexane $(1 \mathrm{~L})$ for $48 \mathrm{~h}$. The residue was extracted with absolute methanol (1 L) for $48 \mathrm{~h}$. The extract was filtered, $80 \%$ of the solvent was removed by distillation at atmospheric pressure and the last trace of methanol was removed under reduced pressure (Yield, $21.86 \%$ ).

\section{Animals}

Male SD rats weighing 150-200 g were obtained from the Institute of Basic Medical Science, Chennai, India. They were acclimatized to animal house conditions, fed commercial pelleted rat chow (Hindustan Lever Ltd, Bangalore, India) and had free access to water. All animals were maintained under standard conditions of temperature $\left(28 \pm 2{ }^{\circ} \mathrm{C}\right)$ and light $(12 \mathrm{~h}$ light/dark cycles). The animals were housed in polypropylene cages $(45 \times 24 \times 15 \mathrm{~cm})$ and fed with standard diet pellets and water ad libitum. Animals were handled according to the regulations of the Institutional Animal Ethical Committee, University of Madras. All the experiments performed on animals were approved and conducted in accordance with the Institutional Animals Ethics Committee (IAEC No. 01/084/09).

\section{H. pylori Lipopolysaccharide}

HP-LPS is a kind gift from Professor Manfred Kist, Institut für Medizinische Mikrobiologie und Hygiene, Freiburg, Germany. It was prepared by the conventional method from 26695 strain of $H$. pylori. The bacteria grown in Brucella broth with $5 \%$ fetal calf serum was pelleted by centrifugation, washed twice with $0.9 \%$ $\mathrm{NaCl}$, heat inactivated for $2 \mathrm{~h}$ in steam and washed twice with $0.9 \% \mathrm{NaCl}$. The pellet was then suspended in $1 \mathrm{~mL}$ $0.9 \% \mathrm{NaCl}$ and lyophilized. It was stored at $4^{0} \mathrm{C}$ until further use.

The optimal dose of HP-LPS to induce gastric ulceration was assessed by oral administration of HP-LPS suspended in saline at different doses of 10, 25, 50, 75 and $100 \mu \mathrm{g}$ per day for 4 consecutive days. Gastric ulcer index was measured as the sum of the length (in $\mathrm{mm}$ ) of each lesion according to Okabe et al. [36]. The concentration of HP-LPS to induce ulcer was determined based on ulcer index of experimental animals.

\section{Dose determination of MEAM}

Male SD rats were divided into 7 groups of six rats. Gastric ulcers were induced in all the groups by 4 days treatment with HP-LPS (50 $\mu$ g per animal per day). Groups 2 to 6 were treated orally with different doses of MEAM dissolved in water $(25,50,100,250$ and $500 \mathrm{mg}$ per $\mathrm{kg}$ body weight) for 10 days after ulcer induction with HPLPS. Group 7 rats, which served as reference control, were treated with Sucralfate $\left(100 \mathrm{mgkg}^{-1}\right.$ dissolved in water and administered orally) for 10 days [37].

After the experimental period, the rats of all the groups were sacrificed by cervical decapitation. The stomachs were removed and cut open along the greater curvature and then examined under a light microscope. Based on the ulcer index, effective dose of treatment was determined.

Further work was carried out with the grouping of animals as below:

\section{Group I: Control \\ Group II: Induced (HP-LPS alone [50 $\mu$ g per animal per day]) \\ Group III: Treated (HP-LPS $50 \mu$ g per animal per day + $250 \mathrm{mg}$ of MEAM per kg body weight. \\ Group IV: Reference control (HP-LPS $50 \mu \mathrm{g}$ per animal per day $+100 \mathrm{mg}$ of Sucralfate per $\mathrm{kg}$ body weight. \\ Group V: Drug control (250 mg of MEAM per kg body weight)}

\section{Pyloric ligation}

Pyloric ligation was done by the method of Shay Komarov [38]. After the experimental period, rats were subjected to pyloric ligation under ether anaesthesia for the collection of gastric juice. Under light anaesthesia, the abdomen was opened by a small midline incision below the xiphoid process; the pyloric portion of the stomach was slightly lifted out and ligated, avoiding damage to its blood supply. The stomach was replaced and the abdominal wall was closed by interrupted sutures.

\section{Determination of acid secretory parameters}

The animals were sacrificed $4 \mathrm{~h}$ after pylorus ligation. Stomach was dissected out, cut open and the gastric juice was drained into a small beaker, and centrifuged at $2000 \mathrm{rpm}$ for $10 \mathrm{~min}$. The supernatant was collected and used for the estimation of volume of gastric juice, $\mathrm{pH}$, free acidity, total acidity, pepsin concentration and acid output. The volume was noted and expressed as $\mathrm{ml} / 100 \mathrm{~g} / 4 \mathrm{~h}$ and $\mathrm{pH}$ was measured using $\mathrm{pH}$ meter. Estimation of free and total acidity in gastric juice was 


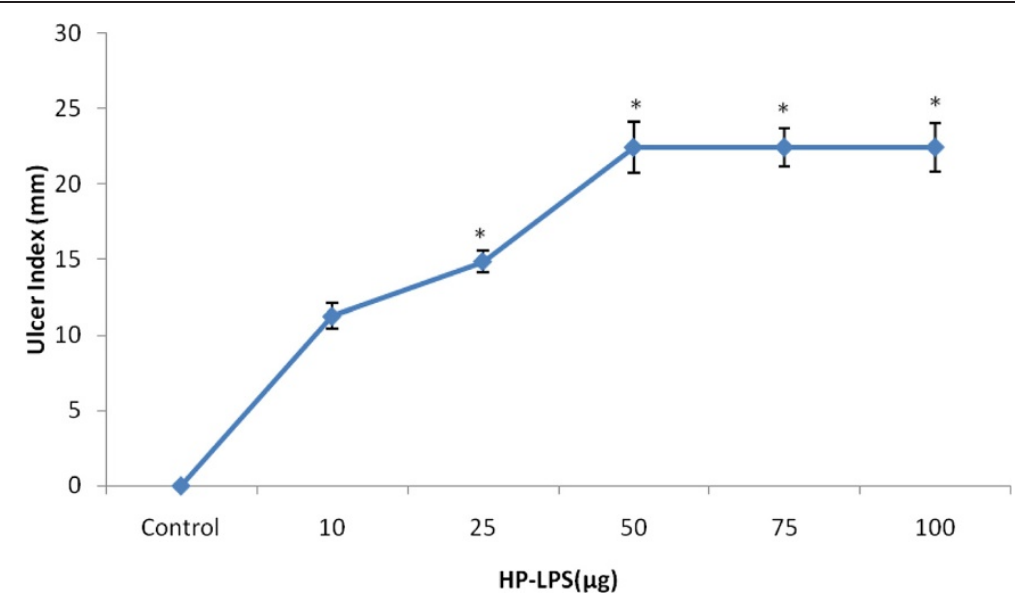

Fig. 1 Dose determination of HP-LPS for the induction of gastric lesions in SD rats. Data are expressed as Mean \pm SD for six animals in each group. Statistical significance: ${ }^{*} p<0.001$, all groups vs control

carried out by the method of Card and Marks [39]. Free acidity and total acidity were determined by titrating with $0.01 \mathrm{~N}$ sodium hydroxide using Toepfer's reagent and phenolphthalein as indicator, respectively. The acidity was expressed as $\mathrm{mEq} / \mathrm{l} / 100 \mathrm{~g}$ and acid output as $\mathrm{mEq} / 100 \mathrm{~g} / 4 \mathrm{~h}$. Pepsin was assayed according to the method of Anson [40] using haemoglobin as substrate. The absorbance of the solution was read at $650 \mathrm{~nm}$. Results were expressed as $\mu \mathrm{mol}$ of tyrosine liberated $/ \mathrm{ml}$.

\section{Preparation of gastric tissue}

The stomach was excised, rinsed in ice-cold physiological saline and homogenized in $0.1 \mathrm{M}$ Tris- $\mathrm{HCl}$ buffer ( $\mathrm{pH}$ 7.4), using a tissue homogenizer with a teflon pestle, at $4{ }^{\circ} \mathrm{C}$. The resultant tissue homogenate was used for biochemical measurements.

\section{Biochemical analysis}

Total protein was estimated by the method of Lowry et al. [41]. Enzymatic antioxidants were measured in the gastric tissues. SOD was measured by the method described by Misra and Fridovich [42]. CAT and GPx were measured according to Takahara et al. [43] and Rotruck et al. [44], respectively. Glutathione reductase (GR) was analyzed by the method of Staal et al. [45]. Nonenzymatic antioxidants, namely Vitamin $\mathrm{E}, \mathrm{C}$ and reduced glutathione (GSH) were measured by the method of Desai [46], Omaye et al. [47] and Ellman [48], respectively. Glutathione-S-transferase activity was assayed by the method of Habig et al. [49]. LPO was determined in the gastric tissue by measuring the formation of thiobarbituric acid reactive substances (TBARS) according to the method of Ohkawa et al. [50].

\section{Histological studies}

Gastric tissues were initially rinsed with ice-cold $0.9 \%$ saline to remove the debris adhering to tissues. The tissues were then fixed in $10 \%$ buffered formalin, routinely processed and embedded in paraffin. Sections $(5 \mathrm{~mm}$ thick) were cut and stained with haematoxylin and eosin.

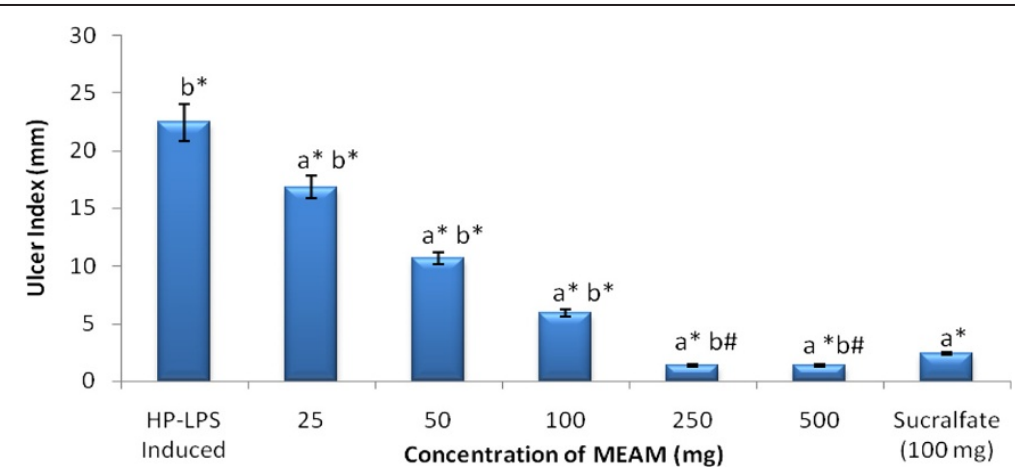

Fig. 2 Effective dose determination of Methanolic extract of Aegle marmelos (MEAM) in HP-LPS induced animals. Data are expressed as Mean \pm SD for six animals in each group. Statistical significance: ${ }^{*} p<0.001 ; \# p<0.05$; NS, not significant. a: all groups vs HP-LPS induced; b: all groups vs rats treated with sucralfate 
Table 1 Effect of MEAM on the levels of acid secretory parameters in gastric juice of experimental rats

\begin{tabular}{|c|c|c|c|c|c|c|}
\hline Groups & Volume of Gastric Juice & $\mathrm{pH}$ & Free acidity & Total acidity & Acid Output & Pepsin concentration \\
\hline । & $1.45 \pm 0.10$ & $4.6 \pm 0.28$ & $32.69 \pm 1.93$ & $58.73 \pm 3.95$ & $85.16 \pm 5.74$ & $155.13 \pm 10.24$ \\
\hline$\|$ & $3.27 \pm 0.27^{a_{*}}$ & $1.92 \pm 0.14^{\mathrm{a} *}$ & $60.17 \pm 4.39^{\mathrm{a} *}$ & $91.82 \pm 5.22^{\mathrm{a} *}$ & $300.25 \pm 21.03^{\mathrm{a} *}$ & $262.91 \pm 17.85^{\mathrm{a} *}$ \\
\hline III & $1.65 \pm 0.12^{b *}$ & $4.45 \pm 0.35^{b *}$ & $33.26 \pm 2.28^{\mathrm{b} *}$ & $59.97 \pm 3.47^{\mathrm{b} *}$ & $98.95 \pm 7.27^{\mathrm{b} *}$ & $174.36 \pm 13.03^{\mathrm{b} *}$ \\
\hline IV & $1.7 \pm 0.11^{\mathrm{b} *}$ & $4.2 \pm 0.27^{b_{*}}$ & $33.9 \pm 2.26^{b *}$ & $60.66 \pm 4.15^{b_{*}}$ & $103.12 \pm 7.59^{\mathrm{b} *}$ & $180.88 \pm 8.87^{\mathrm{b} *}$ \\
\hline V & $1.4 \pm 0.10^{c \mathrm{NS}}$ & $4.7 \pm 0.34^{\mathrm{C} \mathrm{NS}}$ & $32.41 \pm 2.22^{\mathrm{CNS}}$ & $58.11 \pm 4.65^{\mathrm{c} \mathrm{NS}}$ & $81.35 \pm 5.45^{c N S}$ & $155.18 \pm 10.20^{c}$ NS \\
\hline
\end{tabular}

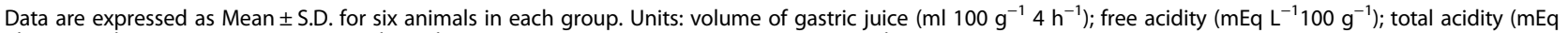
${ }^{-1} \mathrm{~L} 100 \mathrm{~g}^{-1}$ ); acid output (mEq $100 \mathrm{~g}^{-1} 4 \mathrm{~h}^{-1}$ ); pepsin activity $\left(\mu \mathrm{mol}\right.$ tyrosine liberated $\mathrm{mL}^{-1}$ ). Statistical significance: ${ }^{*} p<0.05 ; \mathrm{NS}$, not significant. a: Group II compared with Group I. b: Groups III and IV compared with Group II. c: Group V compared with Group I

The slides were then evaluated under light microscope (Nikon XDS-1B).

\section{Statistical methods}

All the grouped data were evaluated using SPSS/10.0 software. Hypothesis testing method included one-way analysis of variance (ANOVA) followed by least significant difference (LSD) test. $p<0.05$ was considered to indicate statistical significance. All the results were expressed as mean \pm S.D. for six rats in each group.

\section{Results}

\section{Dose determination of HP-LPS}

Figure 1 depicts the dose determination curve of HPLPS to induce gastric ulcer in SD rats. Doses of 10 and $25 \mu \mathrm{g}$ of HP-LPS per day for a period of 4 consecutive days produced slight increase in ulcer index when compared with control, whereas it tends to increase $(p<0.001)$ drastically with 50,75 and $100 \mu \mathrm{g}$ per day for the same period in a dose dependent manner. Hence, $50 \mu \mathrm{g}$ of HP-LPS per day for four days was considered as the minimum effective dose to induce gastric ulcer in SD rats.

\section{Dose determination of MEAM}

Effective dose determination of MEAM treatment against HP-LPS-induced gastric ulcers is shown in Fig. 2. Oral administration of MEAM (25, 50, 100, 250 and $500 \mathrm{mg} / \mathrm{kg}$ ) reduced the gastric ulcer by $2.8 \%, 52.4 \%$, $73 \%, 93 \%$ and $93.98 \%$, respectively, compared to
$89.2 \%$ reduction by sucralfate $(100 \mathrm{mg} / \mathrm{kg})$. There was a significant dose-dependent decrease $(p<0.001)$ in the ulcer index of rats treated with MEAM compared with untreated ulcerated rats. Therefore, $250 \mathrm{mg} / \mathrm{kg}$ of MEAM for 10 days was chosen as the minimum effective dose of MEAM which offered significant protection. Hence, this dose was used for further evaluation of the gastroprotective activity of MEAM.

\section{Effect of MEAM on secretory parameters}

MEAM significantly inhibited the increase in secretory parameters as shown in Table 1. In ulcerated rats (Group II), there was significant increase $(p<0.05)$ in volume of gastric juice, free acidity, total acidity, acid output and pepsin concentration when compared with that of control. However, these parameters were restored to normal levels upon MEAM treatment (Group III), similar to that of control animals (Group I). Sucralfate treated animals (IV) also produced similar results. Drug alone administered animals (Group V) did not show any significant changes in comparison to that of control animals (Group I).

\section{Effect of MEAM on enzymatic antioxidants and non enzymatic antioxidants}

The differences in the activities of enzymatic antioxidants and in the levels of non-enzymatic antioxidants are summarized in Tables 2 and 3, respectively. Upon HP-LPS induction, a significant decrease $(p<0.05)$ in activities of enzymatic antioxidants (SOD, CAT, GPx, GR

Table 2 Effect of MEAM on the activities of enzymatic antioxidants in experimental animals

\begin{tabular}{llllll}
\hline Groups & SOD & CAT & GPx & GR & GST \\
\hline I & $4.43 \pm 0.26$ & $17.63 \pm 0.91$ & $206.28 \pm 14.49$ & $2.64 \pm 0.16$ & $4.82 \pm 0.24$ \\
II & $2.51 \pm 0.18^{\mathrm{a}^{*}}$ & $9.06 \pm 0.61^{\mathrm{a}^{*}}$ & $138.28 \pm 37.39^{\mathrm{a}^{*}}$ & $1.39 \pm 0.11^{\mathrm{a}^{*}}$ & $3.02 \pm 0.19^{\mathrm{a}^{*}}$ \\
III & $4.39 \pm 0.30^{\mathrm{b}^{*}}$ & $17.32 \pm 1.15^{\mathrm{b}^{*}}$ & $205.74 \pm 15.07^{\mathrm{b}^{*}}$ & $2.51 \pm 0.15^{\mathrm{b}^{*}}$ & $4.8 \pm 0.38^{\mathrm{b}^{*}}$ \\
IV & $4.41 \pm 0.28^{\mathrm{b}^{*}}$ & $17.47 \pm 1.24^{\mathrm{b}^{*}}$ & $204.93 \pm 13.40^{\mathrm{b}^{*}}$ & $2.62 \pm 0.18^{\mathrm{b}^{*}}$ & $4.79 \pm 0.26^{\mathrm{b}^{*}}$ \\
V & $4.42 \pm 0.20^{\text {c NS }}$ & $17.58 \pm 1.12^{\text {c NS }}$ & $205.62 \pm 12.67^{c \text { NS }}$ & $2.63 \pm 0.22^{\text {c NS }}$ & $4.81 \pm 0.35^{\text {c NS }}$ \\
\hline
\end{tabular}

Data are expressed as Mean \pm SD for six animals in each group. Units: SOD, Units/mg protein (one unit of the SOD activity is the amount of enzyme required to give $50 \%$ inhibition of epinephrine auto oxidation); CAT, $\mu \mathrm{mol}$ of $\mathrm{H}_{2} \mathrm{O}_{2}$ consumed/min $/ \mathrm{mg}$ protein; $\mathrm{GSH}, \mathrm{nmol} / \mathrm{g}$ tissue; GPx, $\mathrm{nmol} \mathrm{GSH}$ oxidized/min/mg protein; $\mathrm{GR}, \mu \mathrm{mol}$ NADPH oxidized/min/mg protein; GST, $\mu \mathrm{mol}$ of 1-chloro-2,4 dinitrobenzene conjugate formed/min/mg protein. Statistical significance: * $p<0.05 ; \mathrm{NS}$, not significant. a: Group II (HP-LPS induced) compared with Group I (Control). b: Groups III (MEAM treated)and IV (Sucralfate treated) compared with Group II (HP-LPS induced). c: Group V (Drug control) compared with Group I (Control) 
Table 3 Effect of MEAM on the activities of non-enzymatic antioxidants in experimental animals

\begin{tabular}{llll}
\hline Groups & GSH & Vit C & Vit E \\
\hline I & $3.92 \pm 0.23$ & $7.52 \pm 0.33$ & $5.85 \pm 0.32$ \\
II & $1.46 \pm 0.10^{\mathrm{a}^{*}}$ & $4.64 \pm 0.36^{\mathrm{a}^{*}}$ & $3.08 \pm 0.21^{\mathrm{a}^{*}}$ \\
III & $3.89 \pm 0.25^{\mathrm{b}^{*}}$ & $7.48 \pm 0.55^{\mathrm{b}^{*}}$ & $5.8 \pm 0.44^{\mathrm{b}^{*}}$ \\
IV & $3.8 \pm 0.25^{\mathrm{b}^{*}}$ & $7.45 \pm 0.46^{\mathrm{b}^{*}}$ & $5.75 \pm 0.37^{\mathrm{b}^{*}}$ \\
V & $3.88 \pm 0.33^{\text {c NS }}$ & $7.5 \pm 0.54^{\mathrm{CNS}}$ & $5.79 \pm 0.34^{\text {c NS }}$ \\
\hline
\end{tabular}

Data are expressed as Mean \pm S.D. for six animals in each group. Units: GSH, $\mu \mathrm{g} / \mathrm{mg}$ protein; Vitamin $\mathrm{E}, \mu \mathrm{g} / \mathrm{mg}$ protein; Vitamin $\mathrm{C}, \mu \mathrm{g} / \mathrm{mg}$ protein. Statistical significance: ${ }^{*} p<0.05$; NS, not significant. a: Group II (HP-LPS induced) compared with Group I (Control). b: Groups III (MEAM treated)and IV (Sucralfate treated) compared with Group II (HP-LPS induced). c: Group V (Drug control) compared with Group I (Control)

and GST) was observed in Group II animals when compared with that of control animals (Group I). MEAM treatment to ulcerated rats significantly elevated the activities of these enzymes to near normal levels. Highly significant reduction $(p<0.05)$ in the levels of non enzymatic antioxidants (GSH, vitamin $\mathrm{E}$ and vitamin $\mathrm{C}$ ) was evident in the HP-LPS induced animals (Group II). These adverse changes were reversed to normalcy in Group III (MEAM treated) animals. Group IV and V animals did not show any significant changes when compared to control animals.

\section{Effect of MEAM on lipid peroxidation}

Figure 3 depicts the extent of lipid peroxidation in gastric tissue of control and experimental groups of rats. A remarkable elevation in the levels of TBARS was observed in the HP-LPS induced rats when compared to control rats. Treatment with MEAM resulted in a significant decrease $(p<0.05)$ in these levels when compared to ulcerated animals. However, MEAM alone and sucralfate treated animals did not show any significant changes in these levels when compared to that of control animals.

\section{Histological analysis of gastric mucosa}

The effect of MEAM on gastric histology of control and experimental group of animals is depicted in Fig. 4. The gastric mucosa of control rats showed normal architecture with perfect intact structures and regular epithelial lining (Fig. 4a). The gastric mucosa of HP-LPS induced rats showed ulceration, submucosal oedema, inflammation and polymorphonuclear infiltration at the ulcer site (Fig. 4b); whereas, the gastric mucosa of rats treated with MEAM showed no ulceration, instead exhibited regenerating epithelium with mild inflammation (Fig. 4c). However, the gastric mucosa of rats treated with sucralfate also showed slight regeneration of superficial epithelium and with less inflammatory cells (Fig. 4d). The gastric mucosa of drug control animals showed normal architecture similar to that of control animals (Fig. 4e).

\section{Discussion}

Though various pharmacological interventions, alone, or in combination, have proved to be beneficial in treatment of gastric ulcer in several studies, they are not free from their adverse side effects. These detrimental effects have triggered immense interest in a search for alternative herbal medicines. Hence, this study was aimed to find the effect of methanolic extract of unripe fruit of

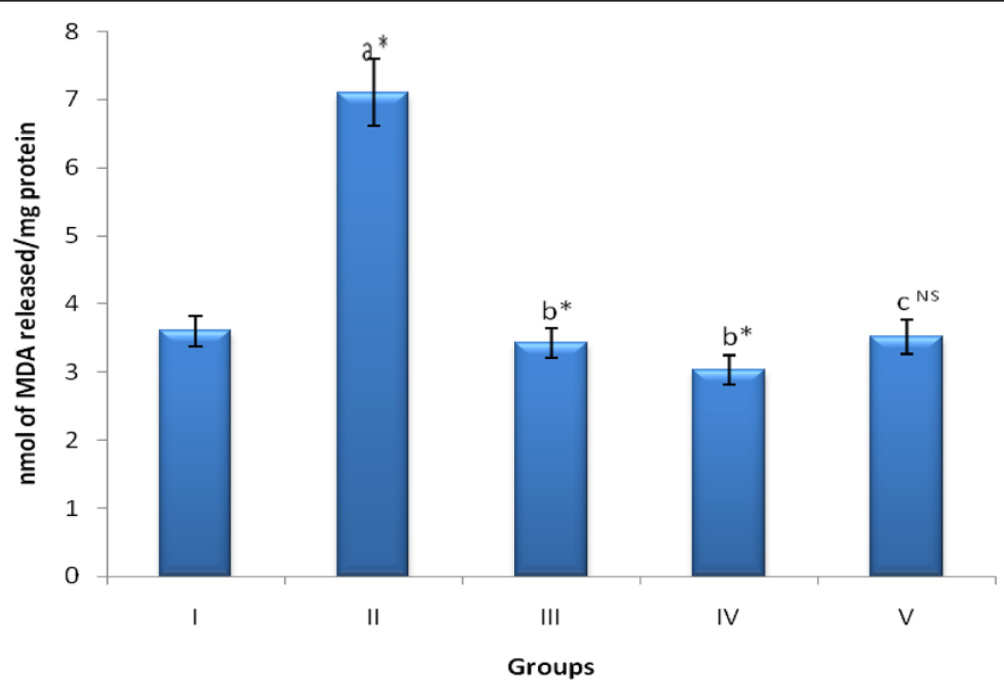

Fig. 3 Effect of MEAM on Lipid Peroxidation in Gastric tissue of Experimental Animals. Data are expressed as Mean \pm SD for six animals in each group. Units: LPO, nmol of MDA released/mg protein. Statistical significance: ${ }^{*} p<0.05$; NS, not significant. a: Group II (HP-LPS induced) compared with Group I (Control). b: Groups III (MEAM treated)and IV (Sucralfate treated) compared with Group II (HP-LPS induced). c: Group V (Drug control) compared with Group I (Control) 


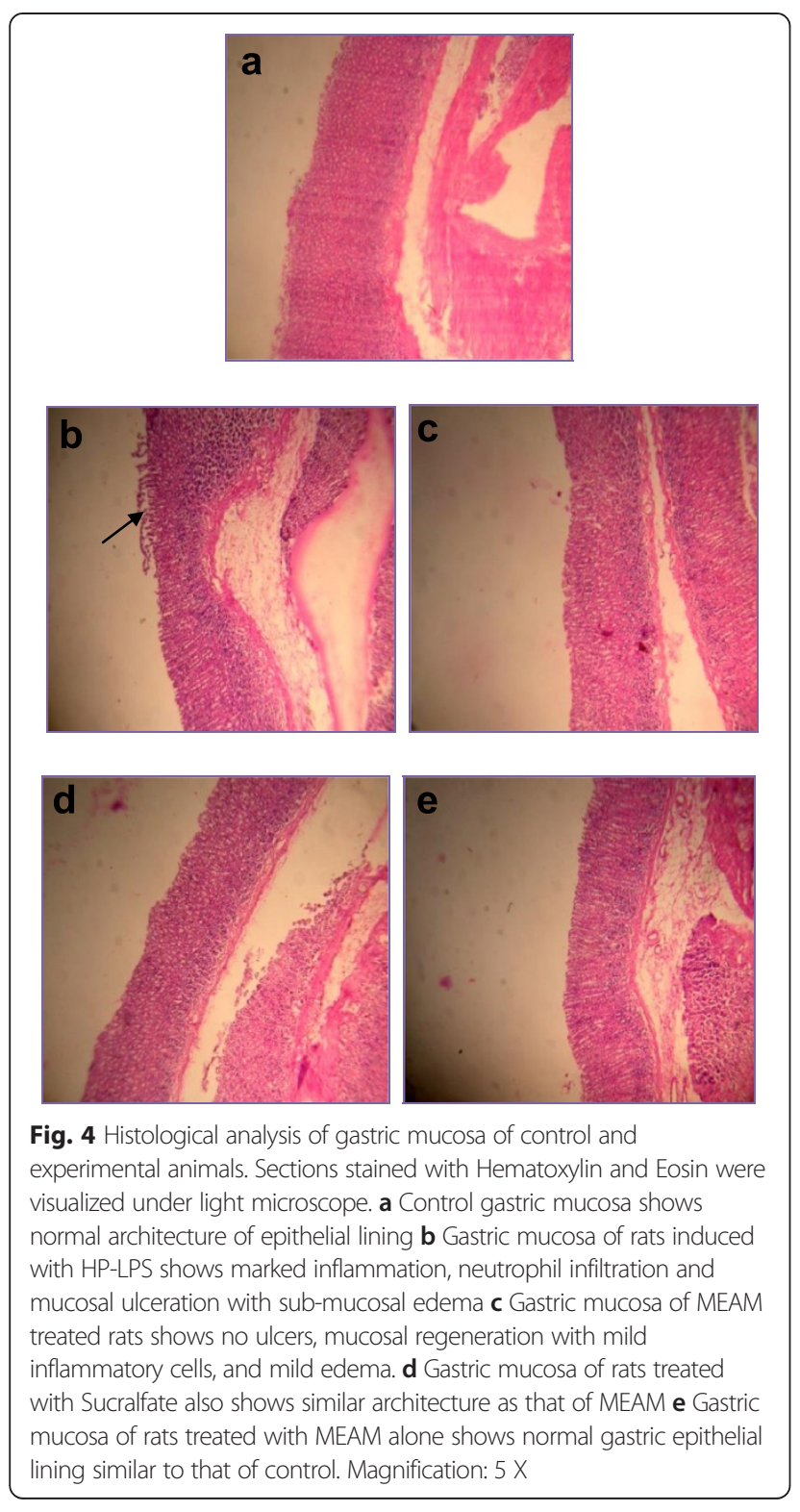

Aegle marmelos against HP-LPS induced gastric ulcer in SD rats.

In this study, a reduction in the ulcer index was noticed in MEAM treated group of animals which clearly points towards the beneficiary effects of the extract. High gastric acid production in patients significantly develops antrum predominant gastritis and is at increased risk for duodenal ulcers. Low gastric acid secretion, in contrast, develops chronic atrophic gastritis and carcinoma [51]. H. pylori infection in patients results in significant increase in acid output and duodenal ulceration, indicating a key role of acid in the pathogenesis of gastro mucosal ulceration. Highly acidic $\mathrm{pH}$ (low $\mathrm{pH}$ ) has been shown to enhance H.pylori induced NF- $\mathrm{kB}$ nuclear binding [52]. Increased acid secretions by HP-LPS contributes to mucosal damage of stomach. At glandular level, HP-LPS can stimulate histamine release from rat enterochromaffin cells which contributes to increase in acid secretion [53]. Pathological effects produced by HPLPS on gastric mucosa were varied depending on the strain of the bacterium, which, in turn, depends on the molecular structure of the LPS preparation. HP-LPS in its pure form obtained from a known pathological strain can stimulate acid secretion and pepsinogen [54]. The present study indicated the stimulated levels of acid secretion by HP-LPS, confirming the role in gastric ulceration. $H$. pylori LPS has also been implicated in a variety of other putative mechanisms of gastric damage that are less well characterized and require independent verification. These include effects on mucus glycosylation, sulfation and epithelial cell interaction and acid secretion [53-57].

Gastric acid secretion can be beneficial while it acts as a part of the host defense mechanism preventing bacterial infection and hence pathogenicity. It has been proposed that the local acid production will determine the extent of colonization by Helicobacter species in the stomach, with decreased acid production promoting the spread of colonization to the acid-producing body of the stomach as opposed to the increased acid production, which tends to restrict colonization, predominantly to the gastric antrum [58]. LPS from $H$. pylori 26695 also stimulated acid secretion as it is evident in this study, confirming its role in gastric mucosal damage. However, on treatment with MEAM, acid secretion was significantly reduced, suggesting its antisecretory role.

Pepsin, a protease present in the gastric lumen, plays a crucial role in ulceration of the stomach and, in fact, gastric acid does not cause ulceration in the absence of pepsin. Pepsinogen, an inactive precursor secreted by the chief cells of the gastric mucosa, is activated by acid in the gastric lumen. $H$. pylori LPS has been implicated in the stimulation of pepsinogen and histamine secretion in association with gastric mucosal damage [10] and the results of the present study coincide with these findings. The anti-secretory effect of MEAM was manifested by the attenuation of acid secretory parameters - acidity, acid output and pepsin activity.

Sucralfate, an ammonium salt of sucrose octasulfate has been shown to prevent the formation of acute gastric lesions induced by various ulcerogens in experimental animals [59]. The potency of Sucralfate in healing and reducing the gastroduodenal ulceration was supported by several clinical trials [60]. The mechanisms by which Sucralfate shows the protective and antiulcer effects were not fully explained but they have been attributed to the binding of the drug to the defective and ulcerated mucosa $[61,62]$, the formation of a protective barrier over the eroded mucosal surface and decrease of 
pepsin $[63,64]$. It is recently reported that Sucralfate may also stimulate the luminal release of prostaglandins, which contribute to the protective and ulcer healing properties of drug [65]. Sucralfate markedly suppresses $H$. pylori infection and the accompanying hypersecretion of acid. These effects are likely to be important mechanisms by which the drug promotes healing of duodenal ulcers [66]. Hence, sucralfate was used as reference control.

An important feature of the pathogenesis of $H$. pylori infection is its persistence in the inflamed gastric mucosa progressing towards peptic ulceration and gastric carcinoma. H. pylori is believed to be a major aetiological agent that causes chronic gastritis, along with the other features, including the lymphoid follicles or lymphoid aggregates, surface epithelial degradation with mucous depletion, and intestinal metaplasia. One characteristic event in gastritis is an infiltration of the sub-epithelial gastric lamina propria by phagocytes, mainly neutrophils and macrophages, which produce large amounts of ROS (reactive oxygen species) in the host defence reaction [67-69]. There is evidence that $H$. pylori infection leads to increased production of $\mathrm{O}_{2}^{-}$via NADPH oxidase in gastric cells, stimulated by lipopolysaccharide as well as xanthine oxidase, another mechanism for the generation of oxygen-derived free radicals [70, 71]. The oxygen radicals, which are produced in gastric epithelial cells infected with $H$. pylori, may reduce the antioxidant defense mechanism and turn on the expression of inflammatory genes, adhesion molecules and mediators stimulating cell proliferation, as well as defensive molecular chaperones in gastric epithelial cells [72].

It is evident that an oral administration of $H$. pylori LPS can trigger distinct inflammatory responses in rat gastric mucosa [44]. ROS are believed to be involved in inflammation, the expression of oncogenes and cell proliferation [68]. These mediators impart oxidative stress on the gastric epithelium in the immediate vicinity.

Normally, the level of oxidative stress is regulated by antioxidants, including vitamin $\mathrm{C}$, cellular reduced glutathione etc., but levels of these antioxidants are decreased during infection. The increased levels of pro-oxidative factors and decreased levels of antioxidants result in severe oxidative stress that can modulate many processes in the gastric epithelium [73]. Cells can survive against chronic oxidative stress by enhancing activities of antioxidant enzymes, thereby protecting cells from DNA damages. The results of the present study demonstrate that MEAM strongly increases both the enzymatic and nonenzymatic antioxidants.

Pharmacological effects of the medicinal plants are well known for their free-radical scavenging properties.
The bael fruit pulp contains many functional and bioactive compounds such as carotenoids, phenolics, alkaloids, coumarins, flavonoids, terpenoids, and other antioxidants which protect us against chronic diseases. Total dietary fiber found in this fruit is divided into insoluble dietary and soluble dietary fiber (mucilage and pectin). In addition, it also contains many vitamins and minerals including vitamin $\mathrm{C}$, vitamin $\mathrm{A}$, thiamine, riboflavin, niacin, calcium, and phosphorus [74-76]. Therefore, bael fruit is one of the important plants used for indigenous traditional medicine [77-80], and it is evident from the above study that Aegle marmelos (Bael) fruit, containing various active constituents, with their synergistic activities, proves effective against HP-LPS induced ulcer.

\section{Conclusion}

In conclusion, A. marmelos fruit extract shows good antioxidant activity. Hence, it exerts its antiulcer effect by inhibiting secretory parameters and activating antioxidant mechanism, thus protecting the gastric mucosa against HP-LPS induced ulceration.

\section{Competing interests}

The authors declare that they have no competing interests.

\section{Authors' contribution}

YGR and SND designed the study. YGR and KS performed the experimental work under the supervision of SND. Preparation of HP-LPS was done by MK. YGR analyzed the data and wrote the manuscript. SND reviewed the manuscript and approved. All authors read and approved the final manuscript.

\section{Acknowledgements}

This study was supported by the funds granted by University Grants Commission, India, to Y. Gayathri Ramakrishna.

\section{Author details}

'Department of Biochemistry, University of Madras, Guindy Campus, Chennai 600025, India. ${ }^{2}$ Institut fur Medizinische, Mekrobiologie und Hygiene, Freiburg, Germany.

Received: 2 February 2015 Accepted: 13 October 2015

Published online: 19 October 2015

\section{References}

1. Falush D, Wirth T, Linz B, Pritchard JK, Stephens M, Kidd M, et al. Traces of human migration in Helicobacter pylori populations. Science. 2003:299:1582-5.

2. Cover TL, Blaser MJ. Helicobacter pylori infection, a paradigm for chronic mucosal inflammation: pathogenesis and implications for eradication and prevention. Adv Intern Med. 1999;41:85-117.

3. Parsonnet J. Helicobacter pylori: the size of the problem. Gut. 1998;43:56-9.

4. Covacci A, Telford JL, Del Giudice G, Parsonnet J, Rappuoli R. Helicobacter pylori virulence and genetic geography. Science. 1999;284:1328-33.

5. Kusters JG, van Vliet AH, Kuipers EJ. Pathogenesis of Helicobacter pylori infection. Clin Microbiol Rev. 2006;19:449-90.

6. Hynes SO, Ferris JA, Szponar B, Wadstrom T, Fox JG, O'Rourke J, et al. Comparative chemical and biological characterization of the lipopolysaccharides of gastric and enterohepatic helicobacters. Helicobacter. 2004;9:313-23.

7. Nielsen H, Birkholz S, Andersen LP, Moran AP. Neutrophil activation by Helicobacter pylori lipopolysaccharides. J Infect Dis. 1994;170:135-9. 
8. Perez-Perez Gl, Shepherd VL, Morrow JD, Blaser MJ. Activation of human THP-1 cells and rat bone marrowderived macrophages by Helicobacter pylori lipopolysaccharide. Infect Immun. 1995;63:1183-7.

9. Yokota S, Amano K, Chiba S, Fujii N. Structures, biological activities and antigenic properties of Helicobacter pylori lipopolysaccharide. Recent Res Dev Microbiol. 2003;7:251-67.

10. Ohkawa H, Ohishi N, Yagi K. Assay for lipid peroxides in animal tissues by thiobarbituric acid reaction. Anal Biochem. 1979;95:351-8.

11. de Boer WA. Helicobacter pylori infection: focus on a "search-and-treat" strategy for ulcer disease. Scand J Gastroenterol. 2000;35 Suppl 232:4-9.

12. Marshall BJ. Helicobacter pylori. Am J Gastroenterol. 1994;89:S116-28.

13. Piotrowski J, Piotrowski E, Skrodzka D, Slomiany BL, Slomiany A. Induction of acute gastritis and epithelial apoptosis by Helicobacter pylori lipopolysaccharide. Scand J Gastroenterol. 1997;32:203-11.

14. Piotrowski J. Lipopolysaccharide a virulence factor of Helicobacter pylori. J Physiol Pharmacol. 1998;49:3-24.

15. Stolte M, Edit S. Helicobacter pylori and the evolution of gastritis. Scand J Gastroenterol. 1996;31 Suppl 214:13-6.

16. Fu S, Ramanujan KS, Wong A, Fantry GT, Drachenberg CB, James SP, et al. Increased expression and cellular localization of inducible nitric oxide synthase and cyclooxygenase-2 in Helicobacter pylori gastritis Gastroenterol. 1999;116:1319-29.

17. Gupta RA, Polk DB, Krishna U, Israel DA, Yan F, DuBois RN, et al. Activation of peroxisome proliferator-activated receptor suppresses nuclear factor kB-mediated apoptosis induced by Helicobacter pylori in gastric epithelial cells. J Biol Chem. 2001;276:31059-66.

18. Slomiany BL, Slomiany A. Blockade of p38 mitogen-activated protein kinase pathway inhibits inducible nitric oxide synthase and gastric mucosal inflammatory responses to Helicobacterpylori lipopolysaccharide by peroxisome proliferator-activated receptor $\mathrm{g}$ activation. Inflammopharmacol. 2001;8:371-82.

19. Moran AP. The role of lipopolysaccharide in Helicobacter pylori pathogenesis. Aliment Pharmacol Ther. 1996;10 Suppl 1:39-50.

20. Piotrowski J, Majka J, Slomiany A, Slomiany BL. Helicobacter pylori lipopolysaccharide inhibition of gastric mucosal somatostatin receptor. Int J Biochem Mol Biol. 1995;36:491-8.

21. Bertrand S, Criscuolo F, Faivre B, Sorci G. Immune activation increases the susceptibility to oxidative tissue damage in zebra finches. Funct Ecol. 2006;20:1022-7.

22. Germano MP, Sanogo R, Guglielmo M, De Pasquale R, Crisafi G, Bisignano G. Effect of Pteleopsis suberosa extracts on experimental gastric ulcers and Helicobacter pylori growth. J Ethnopharmacol. 1998;59:167-72.

23. Korman MG, Bolin TD, Engelmann Jl, Pianko S. Sucralfate as an alternative to bismuth in quadruple therapy for Helicobacter pylori eradication. Helicobacter. 1997;2:140-3.

24. Sezik E, Yesilada E, Tabata M, Honda G, Takaishi Y, Fujita T, et al. Traditional medicine in Turkey VIII. Folk medicine in east Anatolia; Erzurum, Erzincan, Agri, Kars, Igdir provinces. Econ Bot. 1997;51:195-211.

25. World Health Organisation. Summary of WHO guidelines for the assessment of herbal medicines. Herbal Gram. 1993;28:13-4.

26. Pertino M, Rodríguez JA, Theoduloz C, Razmilic I, Schmeda-Hirschmann G. Gastroprotective activity and cytotoxic effect of cyperenoic acid derivatives. J Pharm Pharmacol. 2006;58:1507-13.

27. Banerjee D, Maity B, Bauri AK, Bandyopadhyay SK, Chattopadhyay S. Gastroprotective properties of Myristica malabarica against indometacininduced stomach ulceration: a mechanistic exploration. J Pharm Pharmacol. 2007:59:1555-65.

28. Lapa Fda R, Freitas CS, Baggio CH, Missau FC, Pizzolatti MG, Santos AR, et al. Gastroprotective activity of the hydroalcoholic extract obtained from Polygala paniculata L. in rats. J Pharm Pharmacol. 2007;59:1413-9.

29. Lemos M, de Barros MP, Sousa JP, da Silva Filho AA, Bastos JK, de Andrade SF. Baccharis dracunculifolia, the main botanical source of Brazilian green propolis, displays antiulcer activity. J Pharm Pharmacol. 2007;59:603-8.

30. Rao CV, Vijayakumar M. Protective effect of $(+)$ catechin against gastric mucosal injury induced by ischaemiareperfusion in rats. J Pharm Pharmacol. 2007;59:1103-7.

31. Pace GW, Leaf CD. The role of oxidative stress in HIV disease. Free Radic Biol Med. 1995;19:523-8.

32. Chopra R. Indigenous drugs of India. Calcutta: Academic Publishers; 1982.
33. Shoba FG, Thomas M. Study of antidiarrhoeal activity of four medicinal plants in castor-oil induced diarrhoea. J Ethnopharmacol. 2001;76:73-6.

34. Das SK, Roy C. The protective role of Aegle marmelos on aspirin-induced gastro-duodenal ulceration in albino rat model: a possible involvement of antioxidants. Saudi J Gastroenterol. 2012;18:188-94.

35. Singh P, Dutta SR, Guha D. Gastric mucosal protection by aegle marmelos against gastric mucosal damage: role of enterochromaffin cell and serotonin. Saudi J Gastroenterol. 2015:21(1):35-42.

36. Okabe S, Takata Y, Takeuchi K, Naganuma T, Takagi K. Efects of carbenoxolone $\mathrm{Na}$ on acute and chronic gastric ulcer models in experimental animals. Am J Dig Dis. 1976;21:618-25.

37. Slomiany BL, Piotrowski J, Slomiany A. Effect of sucralfate on gastric mucosal inflammatory responses induced by Helicobacter pylori lipopolysaccharide. Scand J Gastroenterol. 1998:33:916-22.

38. Shay Komarov SA, Fels SS, Meranze D, Gruenstein M, Siplet H. A simple method for the uniform production of gastric ulceration. Gastroenterol. 1945:5:43-55.

39. Card WI, Marks IN. The relationship between the acid output of the stomach following "maximal" histamine stimulation and the parietal cell mass. Clinical Science. 1960;19:147-63.

40. Anson ML. The estimation of pepsin, trypsin, papain and cathepsin with haemoglobin. J Gen Physiol. 1938;22:79-89.

41. Lowry OH, Rosenbrough NJ, Farr AL, Randall RJ. Protein measurement with folin-phenol reagent. J Biol Chem. 1951;193:265-75.

42. Misra HP, Fridovich I. The role of superoxide anion in the auto oxidation of epinephrine and a simple assay for superoxide dismutase. J Biol Chem. 1972;247:3170-5

43. Takahara S, Hamilton HB, Neel JV, Kobara TY, Ogura Y, Nishimura ET. Hypocatalasemia: a new genetic carrier state. J Clin Invest. 1960;39:610-9.

44. Rotruck JT, Pope AL, Ganther HE, Swanson AB, Hafeman DG, Hoekstra WG. Selenium: biochemical role as a component of glutathione peroxidase. Science. 1973;179:588-90.

45. Staal GE, Visser J, Veeger C. Purification and properties of glutathione reductase of human erythrocytes. Biochim Biophys Acta. 1969;185:39-48.

46. Desai ID. Vitamin E, analysis methods for animal tissues. Methods Enzymol. 1984;105:138-47.

47. Omaye ST, Turnbull JD, Sauberlich HE. Selected methods for the determination of ascorbic acid in animal cells, tissues and fluids. Methods Enzymol. 1979;62:3-11

48. Ellman GL. Tissue sulfhydryl groups. Arch Biochem Biophys. 1959;82:70-7.

49. Habig WH, Pabst MJ, Jakoby WB. Glutathione-Stransferase. The first enzymatic step in mercapturic acid formation. J Biol Chem. 1974;249:7130-9.

50. Slomiany BL, Slomiany A. Role of ERK and p38 mitogen-activated protein kinase cascades in gastric mucosal inflammatory responses to Helicobacter pylori lipopolysaccharide. IUBMB Life. 2001;51:315-20.

51. Gschwantler M, Dragosics B. Physiopathology of Helicobacter pylori infection. Acta Med Austriaca. 2000;27:117-21.

52. O'Toole D, Abdel-Latif MM, Long A, Windle HJ, Murphy AM, Bowie A, et al. Low pH and Helicobacter pylori increases nuclear factor kappa B binding in gastric epithelial cells: a common pathway for epithelial cell injury? J Cell Biochem. 2005;96:589-98.

53. Kidd M, Miu K, Tang LH, Perez-Perez Gl, Blaser MJ, Sandor A, et al. Helicobacter pylori lipopolysaccharide stimulates histamine release and DNA synthesis in rat enterochromaffin-like cells. Gastroenterol. 1997;113:1110-7.

54. Padol IT, Moran AP, Hunt RH. Effect of purified lipopolysaccharide from strains of Helicobacter pylori and Helicobacter felis on acid secretion in mouse gastric glands in vitro. Infect Immun. 2001;69(6):3891-6.

55. Durkin E, Moran AP, Hanson PJ. Apoptosis induction in gastric mucous cells in vitro: lesser potency of Helicobacter pylori than Escherichia coli lipopolysaccharide, but positive interaction with ibuprofen. J Endotoxin Res. 2006;12:47-56.

56. Piotrowski J, Slomiany A, Slomiany B. Inhibition of gastric mucosal mucin receptor by Helicobacter pylori lipopolysaccharide. Int J Biochem Mol Biol. 1993:31:1051-8.

57. Slomiany BL, Liau YH, Lopez RA, Piotrowski J, Czajowski A, Slomiany A. Effect of Helicobacter pylori lipopolysaccharide on the synthesis of sulfated gastric mucin. Biochem Int. 1992;27:687-97.

58. Veldhuyzen Van Zanten SJO, Dixon MF, Lee A. The gastric transitional zones: neglected links between gastroduodenal pathology and Helicobacter ecology. Gastroenterol. 1999;116:1217-29. 
59. Nagashima R, Hoshino E, Hinohara Y, Sakai K, Hata S, Nakano H. Effect of sucralfate on ethanolinduced gastric mucosal damage in the rats. Scand J Gastroenterol. 1983;18(3):17-20.

60. Mc Hardy GG. A multicentric double-blind trial of sucralfate and placebo in duodenal ulcer. J Clin Gastroenterol. 1981;3(2):153-7.

61. Giesing DH, Bighley LD, lles RL. Effect of food and antacid on binding of sucralfate to normal and ulcerated gastric and duodenal mucosa in rats. J Clin Gastroenterol. 1981:3(2):111-6.

62. Steiner K, Bühring KU, Faro HP, Garbe A, Nowak H. Sucralfate: pharmacokinetics, metabolism and selective binding to experimental gastric and duodenal ulcers in animals. Arzneimittelforschung. 1982;32:512-8.

63. Nagashima R. Mechanisms of action of sucralfate. J Clin Gastroenterol. 1981;3(2):117-27.

64. Harrington SJ, Schlegel JF, Code CF. The protective effect of sucralfate on the gastric mucosa of rats. J Clin Gastroenterol. 1981;3(2):129-34.

65. Hollander D, Tarnawski A, Gergely H, Zipser RD. Sucralfate protection of the gastric mucosa against ethanol-induced injury: a prostaglandin-mnediated process? Scand J Gastroenterol. 1984;19(101):97-102.

66. Banerjee S, El-Omar E, Mowat A, Ardill JE, Park RH, Watson W, et al. Sucralfate suppresses Helicobacter pylori infection and reduces gastric acid secretion by $50 \%$ in patients with duodenal ulcer. Gastroenterol. 1996;110:947-50.

67. Blaser MJ. Helicobacter pylori and the pathogenesis of gastroduodenal inflammation. J Infect Dis. 1990;161:626-33.

68. Burdon $\mathrm{RH}$. Superoxide and hydrogen peroxide in relation to mammalian cell proliferation. Free Radic Biol Med. 1995;18:775-94.

69. Parsonnet J, Friedman GD, Vandersteen DP, Chang Y, Vogelman JH, Orentreich $\mathrm{N}$, et al. Helicobacter pylori infection and gastric carcinoma. N Engl J Med. 1991;325:1127-31.

70. Benhamida A, Man WK, Mcneil N, Spencer J. Histamine, xanthine oxidase generated oxygen derived free radicals and Helicobacter pylori in gastroduodenal inflammation and ulceration. Inflamm Res. 1998;47:193-9.

71. Teshima S, Tsunawaki S, Rokutan K. Helicobacter pylori lipopolysaccharide enhances the expression of NADPH oxidase components in cultured guinea pig gastric mucosal cells. FEBS. 1999:452:243-6.

72. Kim H. Oxidative stress in Helicobacter pylori-induced gastric cell injury. Inflammopharmacol. 2005:13(1-3):63-74.

73. Ernst $P$. The role of inflammation in the pathogenesis of gastric cancer. Aliment Pharmacol Ther. 1999;13 Suppl 1:13-8.

74. Dikshit BBL, Dutt S. Preliminary chemical examination of Aegle marmelos or the Indian Bel. J Ind Chem Soc. 1930;7:759-64.

75. Parmar C, Kaushal MK. Aegle marmelos Correa. In: Wild Fruits of the SubHimalayan Region. New Delhi: Kalyani Publishers; 1982. p. 1-5.

76. Roy SK, Khurdiya DS. Other Subtropical Fruit. In: Salunkhe DK, Kadam SS, editors. Handbook of Fruit Science and Technology: Production, Composition, Storage and Processing. New York: Marcel Dekker; 1995.

77. Arseculeratne SN, Gunatilaka AAL, Panabokke RG. Studies on medicinal plants of Srilanka: occurrence of pyrolizidine alkaloids and hepatotoxic properties in some traditional medicinal herbs. J Ethnopharmacol. 1981:4:159-77.

78. Karunanayake EH, Welihinda J, Sirimanne SR, Sinnadorai G. Oral hypoglycaemic activity of some medicinal plants of Srilanka. J Ethnopharmacol. 1984;11:223-31.

79. Nagaraju N, Rao KN. A survey of plant crude drugs of Rayalaseema, Andhra Pradesh India. J Ethnopharmacol. 1990:29:137-58.

80. Singh YN. Traditional medicine in Fiji: Some herbal folk cures used by Fij Indians. J Ethnopharmacol. 1986:15:57-88.

\section{Submit your next manuscript to BioMed Central and take full advantage of:}

- Convenient online submission

- Thorough peer review

- No space constraints or color figure charges

- Immediate publication on acceptance

- Inclusion in PubMed, CAS, Scopus and Google Scholar

- Research which is freely available for redistribution

Submit your manuscript at www.biomedcentral.com/submit 